\title{
FISHERY RESOURCES AND ECOLOGY OF TOBA LAKE
}

\author{
Wijopriono'), Kunto Purnomo ${ }^{2)}$, Endi Setiadi Kartamihardja ${ }^{1)}$, and Zulkarnaen Fahmi1) \\ 1) Research Center for Capture Fisheries, Ancol-Jakarta \\ 2) Research Institute for Fisheries Stock Enhancement, Jatiluhur-Purwakarta \\ Received March 3-2009; Received in revised form March 30-2009; Accepted January 4-2010
}

\begin{abstract}
Investigation of stock and distribution of fishery resources was done in Toba Lake in October 2005 , at the time when the wet season prevailed, using acoustic method. Split-beam echosounder SIMRAD EY-60 operated at frequency of $120 \mathrm{KHz}$ and $0.512 \mathrm{~ms}$ pulse duration was used. Results show that there was a difference in fish size composition between areas. Percentage of large fish (TS between -42 and $-33 \mathrm{~dB}$ ) was higher in the waters of northern and western areas of the lake than that of the waters of the eastern and southern areas. Large fishes inhabited the deep areas of the lake while small fishes tended to inhabit the shallow areas close to the shore. Density distribution was discussed in this paper.
\end{abstract}

\section{KEYWORDS: fishery resources, ecology, Toba}

\section{INTRODUCTION}

Fishery is one of important activities and source of earnings for people around the Toba Lake besides tourism. Capture fisheries and fish pond cultures have given significant contribution to local fishers in improvement of their earnings. In the period of 19962001, however, fish pond culture's products experienced a real decrease. Similarly, deceasing trend of fish catches has also showed in capture fisheries. Product of capture fisheries, which initially reached 1,303 tons in 1996, has steadily declined during five years, becoming not more than 1,150 tons in the year 2001, fluctuated at the range of the number, with tendency of rather declines in the following years (Anonymous, 2003)

Inland fishery managers, environmental regulators and aquatic conservationists often require information about fish stocks and communities to discharge adequately their responsibilities. This information must be reliable, timely, cost effective and adequate for its purpose, and based upon appropriate, sound and justifiable data (Hyckley \& Aprahamian, 2000; Hughes \& Hateley, 2002).

Hydroacoustic technique is useful in obtaining quantitative information about fish stocks. In an international context, applications of the techniques in freshwater lakes have matured rapidly, without many of the difficulties faced by workers in the marine field (MacLennan \& Holliday, 1996). Many of these developments have concentrated principally upon effectively copying mobile, vertical, and horizontal beaming, in assessing shoaling fish species in large, deep lakes (Hartmann et al., 1987; Hughes \& Hateley, 2002). However, lake applications like these are rare and still at the infant stages in Indonesia.
Investigation of fishery resources has been done in Danau Toba in 2005, aiming at assessing fish stock and characterization of its ecology. The assessment was done through hydroacoustic technique, where scientific echosounder is used for data collection. This paper presented the first results of the investigation, discussing.

\section{MATERIALSAND METHODS}

Acoustic survey was carried out in October 2005. The survey involved navigating a continuous path of transect lines defined over the Toba reservoir with a $120 \mathrm{kHz}$ SIMRAD EY-60 split-beam echosounder. Transducer of 110 beam with was operated vertically with pulse duration of $0,512 \mathrm{~ms}$. The transducer was mounted on a pool on the side of the boat at a depth of $0.5 \mathrm{~m}$. Data collection was done in the day time with boat speed maintained at 4-5 knot. To keep track on the transect lines a differential GPS system was used.

From data computations, only echocounting was used because previous studies (Guillard, 1991; Kubecka et al., 1992; MacLennan \& Menz, 1996) indicated large differences in interpretation using the echo-integration computation mode, due to the user's choice of setting. Target strength was set to the minimum threshold of $-80 \mathrm{~dB}$, however, targets processed in the subsequent analysis were classified into groups of small fish (target strength from -69 to $60 \mathrm{~dB}$, equivalent to fish length $\leq 5 \mathrm{~cm} \mathrm{TL}$ ), medium fish target strength from -57 to $-45 \mathrm{~dB}$, equivalent to fish length $5-18 \mathrm{~cm} \mathrm{TL}$ ) and large fish (target strength from -42 to $-33 \mathrm{~dB}$, equivalent to fish length 20-70 cm TL) based on target strength-fish length empirical relationships suggested by Love (1977). 
The acoustic survey was done at period where wet season took place. At this season strong westward winds was frequently occurred especially in the evening. In the condition of strong winds and heavy raining, reverberation noise generated at the surface aroused from air bubbles which reached down some times to approximately 2-3 $\mathrm{m}$ depth from the surface at some finite locations. Consequently, data computation was done only for the water column of 5 $\mathrm{m}$ depth from the surface down to the bottom for consistency of the analysis.

Water quality was sampled using kemmerrer water sampler. The water quality parameters measured included water temperature and transparency, phosphate, $\mathrm{pH}$, dissolved oxygen, alkalinity, and total dissolved solid. Plankton samples was collected using Van dorn bottle for every $2 \mathrm{~m}$ water depth down to maximum of $8 \mathrm{~m}$ and filtered through plankton net of $25 \mathrm{~mm}$ mesh size.

\section{RESULTS AND DISCUSSION}

\section{Environment of the Lake}

Toba Lake lies at $905 \mathrm{~m}$ above sea level in North Sumatera Province, covering an area of approximately 113,000 ha (Tjahjo et al., 1998). In the middle of the lake, there is an island, Samosir, with many facilities for tourism along the shore.

Based on the acoustic observation during the study, bottom topography of the lake was mostly flat with steep sloping in the side parts, especially in the north and south sides. Deepest area was found in north side of Samosir island (in front of Silalahi, Paropo, and Tongging villages) with the depth reaching to 600 $\mathrm{m}$. The west (in front of Porsea village) side of the island was more shallow, showing depth of less than $300 \mathrm{~m}$ (Figure 1).

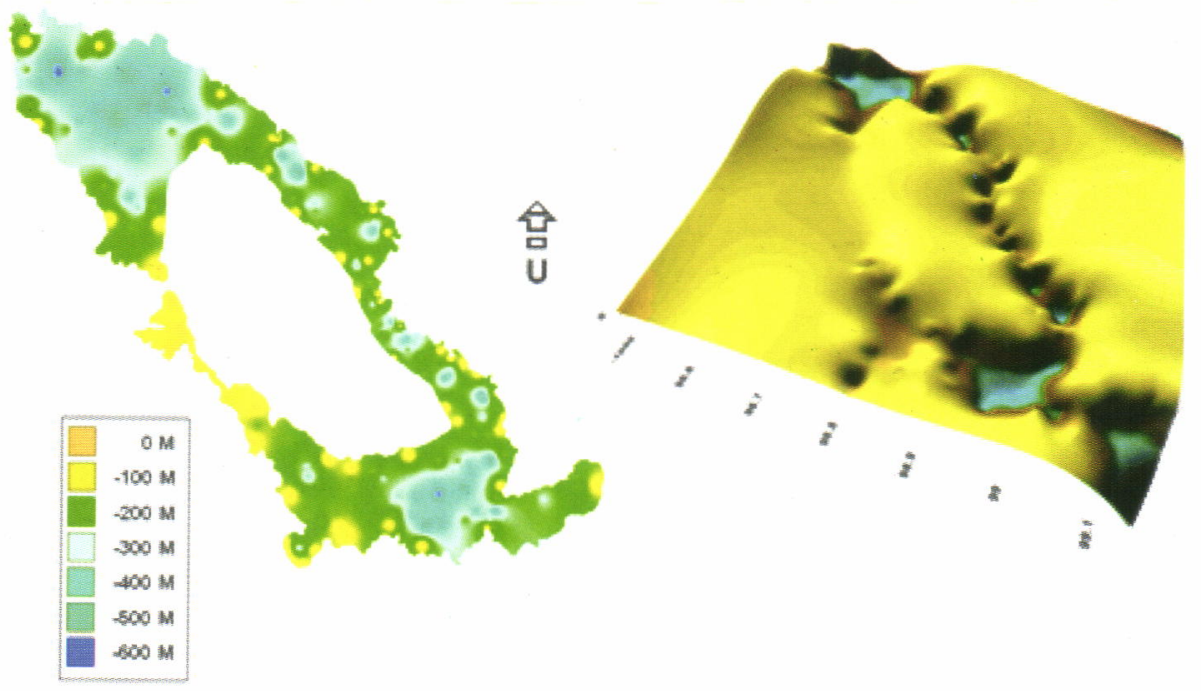

Figure 1. Bathymetry of Toba Lake derived from hydroacoustic detection.

The catchments area is surrounded by mountain and hills with steep to very steep inclination. The area is mostly forest and farms. Deforestation in surrounding areas has given impact to the decrease of inflow water volume, from 2,2 $\mathrm{km}^{3}$ year $^{-1}$ in 1987 to be only $0,9 \mathrm{~km}^{3}$ year ${ }^{-1}$. Seasonal fluctuation of water level is relatively small, below $1.5 \mathrm{~m}$ (Lehmusluoto \& Machmud, 1997).

\section{Water Quality}

Phosphate concentration in Toba Lake ranged between $0.290-0.679 \mathrm{mg} \mathrm{L}^{-1}$ with the average of 0.547 $\mathrm{mg} \mathrm{l}^{-1}$. Following Schmittou (1991) this was equivalent to $0.239 \mathrm{mg} \mathrm{L}^{-1}$ or $239 \mathrm{i} \mathrm{g} \mathrm{L-1}$ of total phosphorus level.
The upper layer of the lake exhibited high turbidity as suspended solids reached $64.3-71.0 \mathrm{mg} \mathrm{L}^{-1}$, reducing light penetration. Secchi disk readings showed the water transparency at the range of 4.8-10.2 $\mathrm{m}$, far lower than that of first investigation values, 13.5-15.0 m (Ruttner, 1931). Conductivity was recorded at the range of 96.0-106.5 i S cm-1, varying with water columns and locations. $\mathrm{pH}$ level was around neutrality, standing between 6.8 and 7.7 .

Water temperature varied between areas and strong stratification was exhibited vertically (Figure 2a). Surface temperature ranged between 25.5 and $28^{\circ} \mathrm{C}$ with northwest-southeast gradient. The decrease of temperature was vertically faster and more extensive 
toward the southeast. Sharp decrease was exhibited at depth layer of less than $20 \mathrm{~m}$ in the southeast area, showing of strong difference with its upper layer. Another water quality parameter, dissolved oxygen, recorded at values of 7.2-7.4 $\mathrm{mg} \mathrm{L}^{-1}$, and decreasing to be not more than $2 \mathrm{mg} \mathrm{L}^{-1}$ at the depth of $200 \mathrm{~m}$ (Figure 2b).

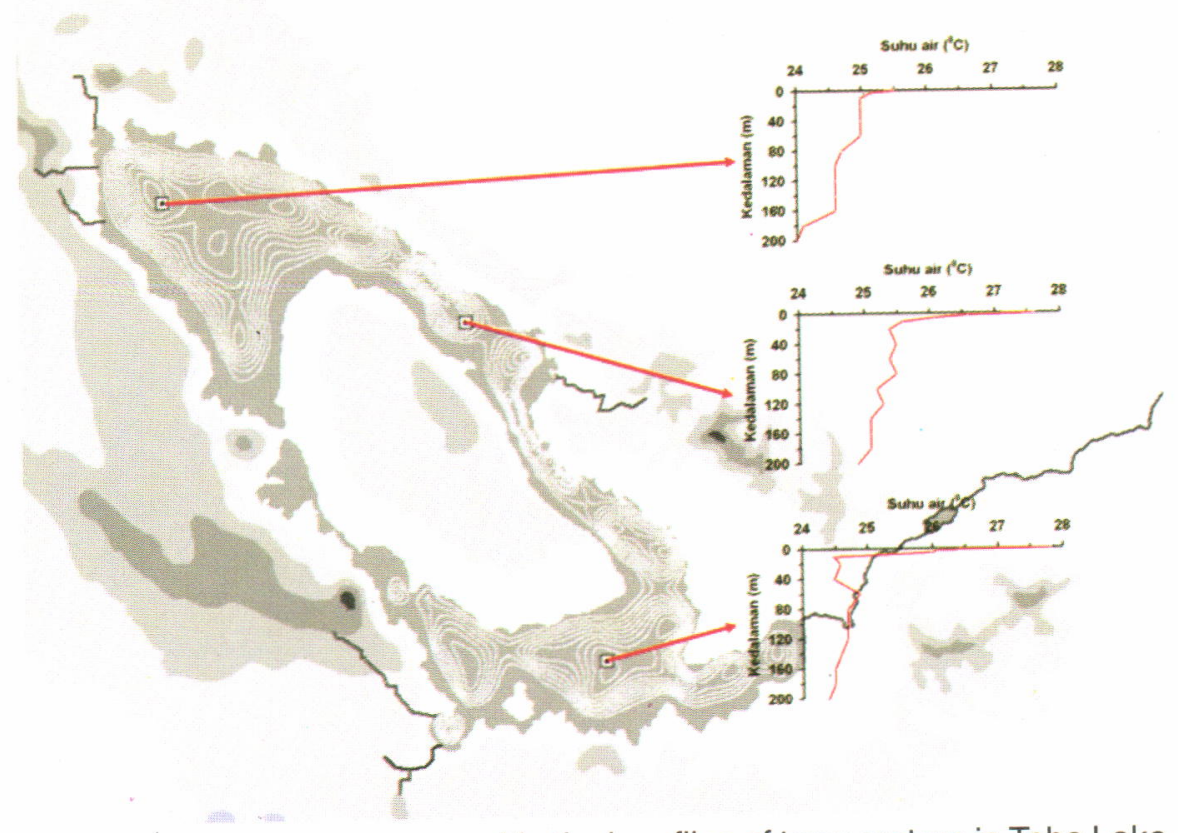

Figure 2a.

Vertical profiles of temperature in Toba Lake.

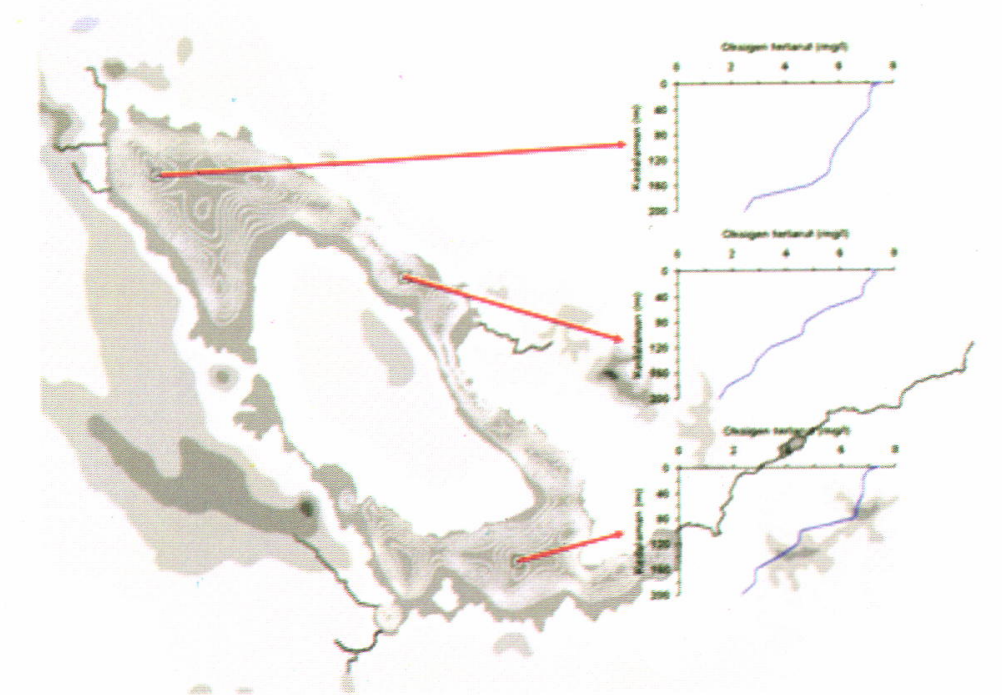

Figure 2b.

Vertical profiles of dissolved oxygen in Toba Lake.

Abundance of phytoplankton ranged between 15,000 and $33,400 \mathrm{cell} / \mathrm{L}$, dominated by Chlorophyceae, while zooplankton was between 3,200 and 11,000 ind./L, dominated by Rotifer (Figure 3).
Vertically, maximum abundance of phytoplankton was observed at depth layer of $4 \mathrm{~m}$, while that of zooplankton was found at the deeper layer ( $6 \mathrm{~m}$ deep). 
Figure 3.

\section{Fish Resources}

Variety of fish species was found in Toba Lake. There 11 fish species were most frequently caught by fishermen as recorded along the study period. The species included Tor duoronensis (ikan batak), Hampala macrolepidota (hampal), Oreochromis mossambicus (mujair), Oreochromis niloticus (nila), Channa striata (gabus), Oxyeleotris marmorata (betutu), Clarias batrachus (lele), Cyprinus carpio (mas), Barbodes gonionotus (tawes), Anabas testudineus (betok), and Mystacoleucus padangensis (bilih). They were commonly caught by liftnet and traps. Fisheries activities were concentrated in the littoral zones, i.e., in the north and southeast of the lake.

It should be noted that there were 2 fish species of introduction, i.e. Oxyeleotris marmorata (betutu) and Mystacoleucus padangensis (bilih), transferring from Jatiluhur Reservoir in 1998 and from Singkarak Lake

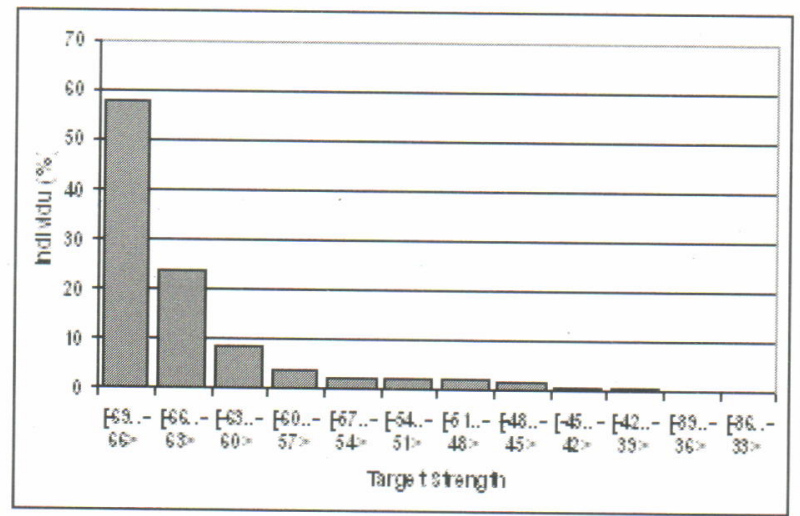

in 2003, respectively. Population of these two species grew significantly, giving respective contribution of more than 400 and 600 tons to the total fish production in 2005 (PRPT,2005).

\section{Fish Stock and Distribution}

Acoustic observations indicated the fish with target strength of (-69)-(-67) dB dominated $50-60 \%$ of the samples acquired. This was equivalent to small fish group with sizes of $1.4-2.0 \mathrm{~cm}$ TL. Owing to fish sample collected, this group was likely as Mystacoleucus padangensis (bilih). Fish with target strength of (-57)-(-45) dB (equivalent to medium group, $5-18 \mathrm{~cm} \mathrm{TL}$ ) and of (-42)-(-33) dB (equivalent to large group, $20-70 \mathrm{~cm} \mathrm{TL}$ ) contributed not more than $3 \%$ to the total samples, respectively. Target strength distributions of the acoustic samples acquired (Figure 4 and 5) gave an indication that large fish group agglomerated more in the northern and western areas than the others.

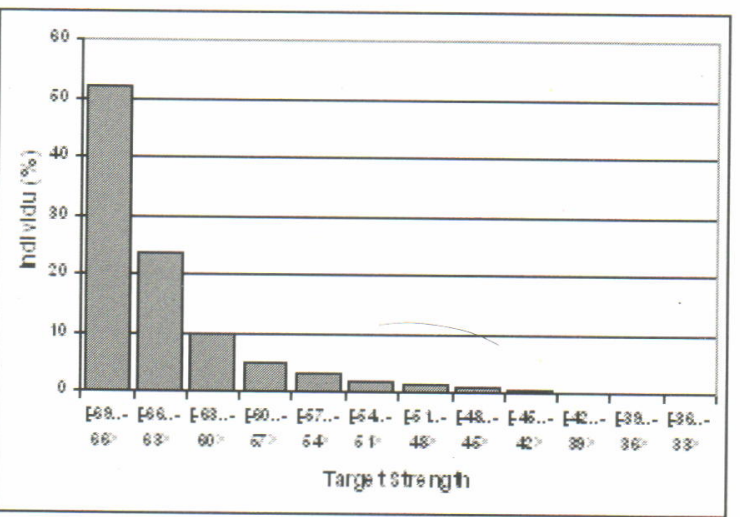

Figure 4. Target strength distributions of fish in the northern (left) and southern (right) parts of Toba Lake. 

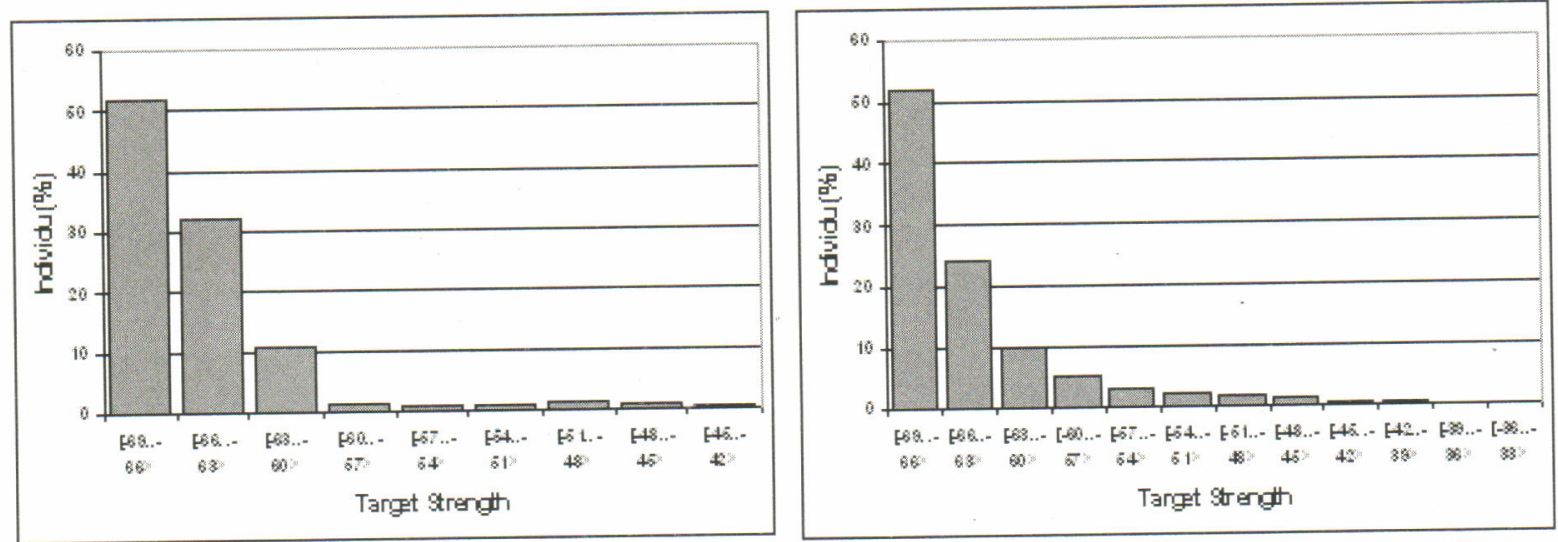

Figure 5.

Target strength distributions of fish in the western (left) and eastern (right) parts of Toba Lake.

Fish tend to agglomerate in the shallow bays and littoral zones, at the depth layer of less than $40 \mathrm{~m}$, with various densities. However, the density in the middle-deep area was found to be much lower. Above

the shelf break, several loosely shoaling fish exhibited along the path of other small organism (plankton and most likely their prey), especially occurred in the morning at the depth of 20-30 m (Figure 6).

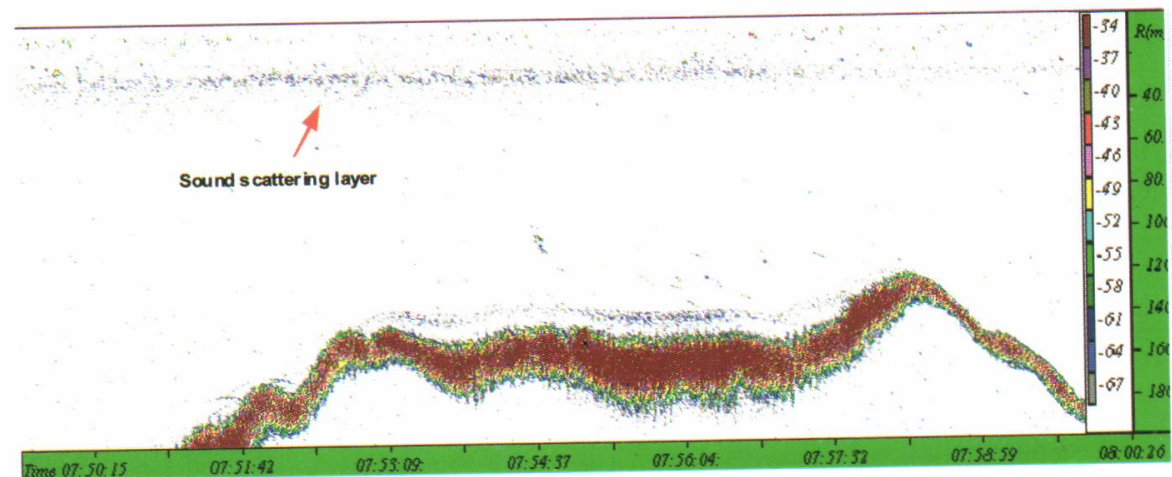

Figure 6. Echogram showing fish traces around the path of other organism (presumable plankton) forming sound scattering layer at the depth of 20-30 m.

Taking Samosir Island as a georeference, estimated fish density for each subarea was presented

as in Table 1. The density was presented in number of fish and total weight (biomass) per hectare.

Table 1.

Estimated fish density in various subareas in Toba Lake with georereference of Samosir Island

\begin{tabular}{|c|c|c|c|c|c|c|c|}
\hline \multirow{2}{*}{ No. } & \multirow{2}{*}{ Sub-area } & \multicolumn{2}{|c|}{ Fish density } & \multirow{2}{*}{ No. } & \multirow{2}{*}{ Sub-area } & \multicolumn{2}{|c|}{ Fish density } \\
\hline & & Fishihectare & Kghectare & & & Fishhectare & Kghectare \\
\hline 1. & Northern & 5,778 & 110.3 & 4. & Eastern & 11.378 & 56.1 \\
\hline 2. & Southern & 11.157 & 64.4 & 5. & Average & 8.409 & 74.8 \\
\hline 3. & Western & 1.178 & 87.2 & & & & \\
\hline
\end{tabular}

It can be seen that comparison of fish number and its total weight (columns 3 and 4 ) in Table 1 suggested the difference of average fish sizes of each sub-area. Fish sizes inhabited sub-area of Northern and the Western of Samosir Island was averagely larger than those inhabited sub-area of the Eastern and Southern. Along the acoustic transect, large fish were most frequently observed in the deep waters, while small fish were found around bay and shallow waters. Variation of fish abundance was showed in Figure 7. 
Figure 7.

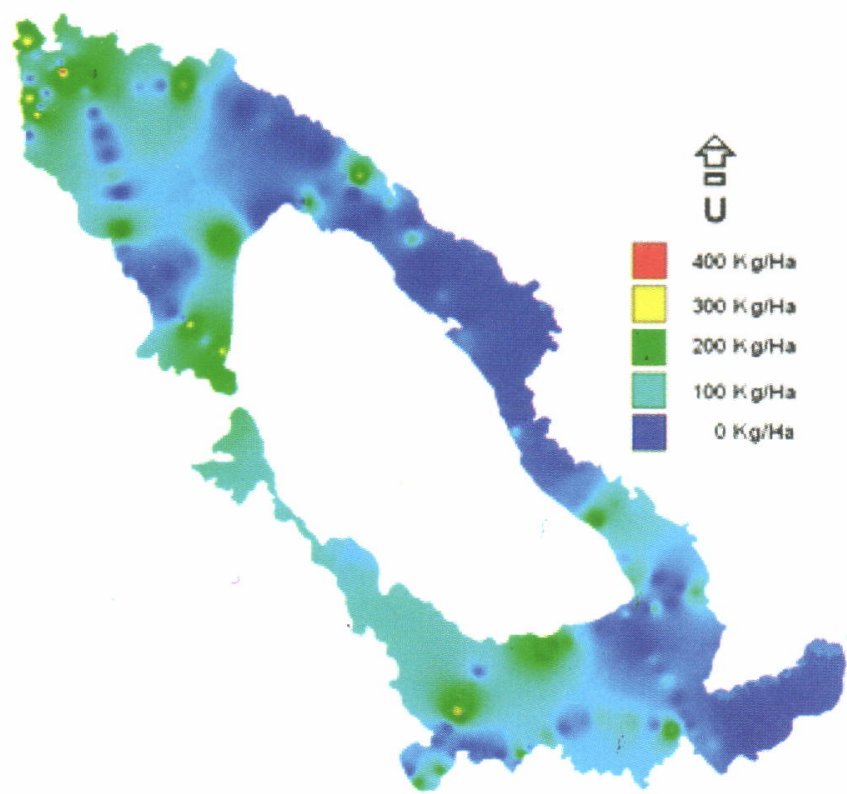

\section{DISCUSSION}

Lake trophy has been shown to be the most meaningful parameter to predict biomass, fish production and fish yield in lakes (Downing \& Plante, 1993; Bramick, 2002). In this context, total phosphorus has been highlighted as an appropriate starting point for estimates (Downing et al., 1990; Quiros, 1991). Besides its significant correlation with biomass or yield, TP is much less expensive to measure, and more representative, than for instance chlorophyll-a or primary production.

Result of the analysis showed that total phosphorus level of Toba Lake was $0.239 \mathrm{mg} \mathrm{L}^{-1}$ or $239 \mathrm{i} \mathrm{g} \mathrm{L}^{-1}$. This was equivalent to index value 83.12 of Carlson (Carlson, 1977), suggesting that the lake was mesotrophy. However, the first investigation carried out in the beginning of 1930's classified Toba Lake into oligotrophy (Ruttner, 1931). Change of water quality of the lake is considered caused by anthropogenic activities.

A number of different approaches have been developed to estimate either fish biomass, fish production or fish yield (catch) in lakes and reservoirs (Knoesche \& Barthelmes, 1998). In this study, hydroacoustic technique has been used to obtain quantitative information about fish stocks. Applications of the technique in freshwater lakes were rare and still at the infant stages in Indonesia, although in an international context they have been matured (MacLennan \& Holliday, 1996).
Result of analysis on acoustic data suggested that potential harvesting of fish in Toba Lake was estimated between 4,226-6,762 ton/year, taking the maximum sustainable yied was $50-80 \%$ of the total biomass. Using primary productivity approach, Krismono \& Sarnita (2003) estimated that potential harvesting of fish stand between 2,519-7,309 ton/year. Meanwhile the fish production reached 4,462 tons in 2005 (PRPT, 2005).

\section{CONCLUSIONS}

1. Water quality of Toba Lake has gradually changed compared to that of seven decades ago when the first investigation was made. Trophic status of the lake has changed from oligotrophy to be mosotrophy.

2. Based on the acoustic samples, it was considered that small fish of $1.4-2.0 \mathrm{~cm}$ total length dominated $50-60 \%$ of the population. Owing to fish sample collected, this group is considered as Mystacoleucus padangensis (bilih), an introductory species. Fish with sizes of $20-70 \mathrm{~cm}$ TL contributed not more than $3 \%$ to the total samples, respectively.

3. Fish tend to agglomerate in the shallow bays and littoral zones, at the depth layer of less than 40 $\mathrm{m}$, with various densities. Taking the maximum sustainable yied was $50-80 \%$ of the total biomass, potential harvesting of fish in Toba Lake was estimated between 4,226-6,762 ton/year. 


\section{ACKNOWLEDGEMENT}

This study is based on the data collected from the project of ecology and fisheries resource assessment of Toba Lake in 2005-2006 funded by Research Center for Capture Fisheries, Jakarta. We thank to the Director of RCCF for the funding support.

\section{REFERENCES}

Anonymous. 2003. Perikanan Perairan Danau. Dinas Perikanan dan Kelautan Provinsi Sumatera Utara, Medan. 21 pp.

Bramick, U. 2002. Estimation of the fish yield potential of lakes in north-east Germany. In I. G. Crowx (ed) Management and Ecology of River Fisheries. Oxforrd. Fishing News Books. Blackwell Science. $444 \mathrm{pp}$.

Carlson, R. E. 1977. A trophic state index for lakes. Limnol. Oceanogr. V. 22 (2): 361-369 pp.

Downing, J. A. \& C. Plante. 1993. Production of fish populations in lakes. Canadian Journal of Fisheries and Aquatic Science. 50: 110-120.

Downing, J. A., C. Plante, \& S. Lalonde. 1990. Fish production correlated with primary productivity, not morphoedaphic index. Canadian Journal of Fisheries and Aquatic Science. 47: 1,929-1,936.

Guillard, J. 1991. Estimation des stocks pisciaries lacustres par echointegration: Problemes methodologiques. Doctorat Thesis. Cl. Bernard University. $156 \mathrm{pp}$.

Hartmann, J., E. Dahm, J. Dawson, P. Doering, S. Jurgensen, T. Lindem, H. Loffler, G. Raemhild, \& V. Volzke. 1987. EIFAX experiments on pelagic fish stock assessment by acoustic methods in lake Tegel. Rome. FAO. EIFAC Occasional Paper 17. $26 \mathrm{pp}$.

Hughes, S. \& J. Hateley. 2002. Hydroacoustic fish stock assessment in lakes in England and Wales. In I. G. Crowx (ed) Management and Ecology of River Fisheries. Oxforrd. Fishing News Books. Blackwell Science. 444 pp.

Hyckley, P. \& M. Aprahamian. 2000. Fisheries science and managerial imperative. In I. G. Crowx (ed) Management and Ecology of River Fisheries. Oxforrd. Fishing News Books. Blackwell Science. $444 \mathrm{pp}$.
Knoesche, R. \& D. Barthelmes. 1998. A new approach to estimate lake fisheries yield from limnological basic parameters and first results. Limnologica. 28: $133-144$.

Krismono, A. S. N. \& A. S. Sarnita. 2003. Penilaian ulang lima lokasi suaka perikanan di Danau Toba berdasarkan kualitas air dan parameter perikanan lainnya. Jurnal Penelitian Perikanan Indonesia. 9 (3): 1-11.

Kubecka, J., A. Duncan, \& A. Butterworth. 1992. Echo counting or echo integration for fish biomass assessment in shallow waters. In M. Weidert (ed.). European Conference on Underwater Acoustics. London. Elsevier. 129-132.

Lehmusluoto, P. \& B. Machmud. 1997. National inventory of the major lakes and reservoirs in Indonesia. General limnology. Revised edition. Expedition Indodanau Technical Report. Helsinki. $72 \mathrm{pp}$.

Love, R. H. 1977. Target strength of an individual fish at any aspect. Journal of the Acoustical Society of America. 62: 1,397-1,403.

MacLennan, D. N. \& A. Menz. 1996. Interpretation of in situ target-strength data. ICES Journal of Marine Science, Fisheries, and Plankton Acoustics. 53. 233-236.

MacLennan, D. N. \& D. V. Holliday. 1996. Fisheries and plankton acoustic: Past, present, and future. ICES Journal of Marine Science. 53: 513-516.

PRPT. 2005. Riset pemetaan kapasitas sumber daya ikan dan lingkungan di Danau Toba, Sumatera Utara. Laporan Tahunan/Akhir Pusat Riset Perikanan Tangkap. Jakarta. 56 pp.

Quiros, R. 1991. Empirical relationships between nutrienis, phyto-and zooplankton and relative fish biomass in lake $s$ and reservoirs of Argentina. Verhandlungen-Internationale Vereinigung fur Theoretische und angewandte Limnologie 24. 1,198-1,206.

Ruttner, F. 1931. Hydrographische und hydrochemishe Beobachtungen auf Java, Sumatera und Bali. In A. Thienemann. Archiv für hydrobiologie. Organ Der Internationalen Fûr Theoretische und 
Angewandte Limnologie. Supplement-Band VIII. E. Schweizerbart'sche Verlagsbuchhandlung (Erwin Nägele) G. m. b. H. Stuttgart. 464 pp

Schmittou, H. R. 1991. Cage culture: A Method of Fish Production in Indonesia. FRDP. Central Research Institute for Fisheries. Jakarta. Indonesia. $114 \mathrm{pp}$.
Tjahjo, D. W. H., A. S. Nastiti, K. Purnomo, E. S. Kartamihardja, \& A. S. Sarnita. 1998. Potensi sumber daya perikanan di Danau Toba, Sumatera Utara. Jurnal Penelitian Perikanan Indonesia. 4 (1): 1-12. 